\title{
Heterogeneous Photo-Fenton Reaction Catalyzed by Nanosized Iron Oxides for Water Treatment
}

\author{
Chuan Wang, ${ }^{1}$ Hong Liu, ${ }^{1}$ and Zhimin Sun ${ }^{2}$ \\ ${ }^{1}$ Chongqing Institute of Green and Intelligent Technology, Chinese Academy of Sciences, Chongqing 401122, China \\ ${ }^{2}$ Guangzhou Municipal Engineering Design \& Research Institute, Guangzhou 510060, China
}

Correspondence should be addressed to Hong Liu, liuhong@cigit.ac.cn

Received 7 June 2012; Accepted 31 July 2012

Academic Editor: Jiaguo Yu

Copyright (C) 2012 Chuan Wang et al. This is an open access article distributed under the Creative Commons Attribution License, which permits unrestricted use, distribution, and reproduction in any medium, provided the original work is properly cited.

\begin{abstract}
Great efforts have been exerted in overcoming the drawbacks of the Fenton reaction for water treatment applications. The drawbacks include $\mathrm{pH}$ confinement, handling of iron sludge, slow regeneration of $\mathrm{Fe}(\mathrm{II})$, and so forth. This paper highlights the recent developments in the heterogeneous photo-Fenton reaction which utilizes nanosized iron oxides as catalyst for maximizing the activity due to the enhanced physical or chemical properties brought about by the unique structures. This paper also summarizes the fundamentals of the Fenton reaction, which determine the inherent drawbacks and associated advances, to address the advantages of iron oxides and nanosized iron oxides. Tips for applying this method in water treatment are also provided. Given that the environmental effect of nanosized iron oxides is not yet well established, rapid research growth may occur in the near future to advance this promising technology toward water treatment once it is smartly coupled with conventional technologies.
\end{abstract}

\section{Introduction}

Large amounts of wastewater from industries, agriculture, and households are produced every day, and organic wastewater has a dominant proportion. The organic content must be reduced to a sufficiently low level acceptable for the receiving waters. Organic pollutants are highly toxic and need to be subjected to physicochemical approaches such as advanced treatment or pretreatment.

The Fenton reaction is frequently investigated as a physicochemical technology because it involves highly oxidative activity of hydroxyl radicals $\left({ }^{\bullet} \mathrm{OH}\right)$ with respect to the substrates [1]. The ${ }^{\bullet} \mathrm{OH}$ is the second most powerful oxidizing species after fluorine in aqueous media, and it is believed to destroy or even mineralize most organic substrates nonselectively in advanced oxidation processes [25].

Fenton reaction uses $\mathrm{H}_{2} \mathrm{O}_{2}$ and ferrous ion $\left(\mathrm{Fe}^{2+}\right)$ to produce ${ }^{\bullet} \mathrm{OH}$, as shown in the following reactions [1]:

$$
\begin{aligned}
& \mathrm{Fe}^{2+}+\mathrm{H}_{2} \mathrm{O}_{2} \longrightarrow \mathrm{Fe}^{3+}+\cdot \mathrm{OH}+\mathrm{OH}^{-}, \quad k_{1}=76 \mathrm{M}^{-1} \mathrm{~S}^{-1} \\
& \mathrm{Fe}^{3+}+\mathrm{H}_{2} \mathrm{O}_{2} \longrightarrow \mathrm{Fe}^{2+}+\mathrm{HO}_{2} \cdot+\mathrm{H}^{+}, \quad k_{2}=0.02 \mathrm{M}^{-1} \mathrm{~S}^{-1}
\end{aligned}
$$

$$
\begin{aligned}
& \mathrm{Fe}^{2+}+\mathrm{HO}_{2}{ }^{\bullet} \longrightarrow \mathrm{Fe}^{3+}+{ }^{\bullet} \mathrm{OH}_{2}^{-}, \quad k_{3}=1.3 \times 10^{6} \mathrm{M}^{-1} \mathrm{~S}^{-1} \\
& \mathrm{Fe}^{3+}+\mathrm{HO}_{2} \cdot \longrightarrow \mathrm{Fe}^{2+}+\mathrm{O}_{2}+\mathrm{H}^{+}, \quad k_{4}=1.2 \times 10^{6} \mathrm{M}^{-1} \mathrm{~S}^{-1} \\
& \mathrm{H}_{2} \mathrm{O}_{2}+\mathrm{HO}^{\bullet} \longrightarrow \mathrm{HO}_{2}^{\bullet}+\mathrm{H}_{2} \mathrm{O}, \quad k_{5}=2.7 \times 10^{7} \mathrm{M}^{-1} \mathrm{~S}^{-1}
\end{aligned}
$$

During the process, $\mathrm{Fe}^{2+}$ is oxidized to ferric ion $\left(\mathrm{Fe}^{3+}\right)$ and then reduced back to $\mathrm{Fe}^{2+}$. Thus, iron is considered to function as a catalyst. Several studies indicate that $\mathrm{Fe}^{3+}$ can also mediate the Fenton reaction [6-8]. In practice, an $\mathrm{Fe}^{2+}$ solution almost inevitably contains $\mathrm{Fe}^{3+}$; thus, the Fenton reaction is actually mediated by the mixture of $\mathrm{Fe}^{2+}$ and $\mathrm{Fe}^{3+}$.

Apart from its well-established high efficiency, the Fenton reaction has attracted much attention because of its environmental friendliness, that is, nontoxic products (1)(6) However, engineers encounter two drawbacks when implementing the Fenton reaction in water treatment. First, the working $\mathrm{pH}$ for the reaction is confined to $2.0-4.0$, and the highest efficiency of the Fenton reaction occurs at $\mathrm{pH}$ 2.8-3.0 [9, 10]. At $\mathrm{pH}$ higher than 4.0, the Fenton reaction appears to terminate due to the precipitation of $\mathrm{Fe}^{3+}$. Second, 
the amount of iron ions decreases because $\mathrm{Fe}^{3+}$ precipitates after use due to its extremely low solubility product constant even at the $\mathrm{pH} 4.0$.

The escape of iron ions can be prevented and the range of the working $\mathrm{pH}$ can be widened once the Fenton reaction evolves into a heterogeneous Fenton reaction that utilizes solid iron oxides as a catalyst instead of free iron ions $[10,11]$. A light source can also elevate the reaction efficiency by enhancing the generation of $\bullet \mathrm{OH}$ and recycling $\mathrm{Fe}(\mathrm{II}) / \mathrm{Fe}(\mathrm{III})$. Nanosized iron oxides further exhibit improved catalytic activity because of their large surface area, which potentially provides more active sites for the generation of $\bullet \mathrm{OH}$ [12-19].

This review focuses on the heterogeneous photo-Fenton reaction catalyzed by nanosized iron oxides. Iron oxides are commonly found in nature and can be easily prepared in the laboratory. They are commonly considered to be nontoxic, environmentally friendly compounds similar to free iron ions, in contrast to other Fenton-like ions such as cobalt ions $[20,21]$. In particularly, the nanosized iron oxides have been acknowledged to have unique properties including stronger adsorptive and catalytic activities. Moreover, the solid iron oxides are subjected to manipulate to achieve special physical and chemical structures, which serve to bring added advantages to the target reactions. Consequently, the Fenton reaction using nanosized iron oxides should be paid, as it is, great attention. Besides, UV-based technologies [2224] have also been widely tested and already implemented in wastewater treatment plants. Thus, the utilization of a light source in the heterogeneous photo-Fenton reaction, which aids to enhance the Fenton reaction by generating more radicals, is expected to be widespread as it has already been. From an economic point of view, once the solid iron oxides become reusable, the operation cost of the Fenton reaction can be considerably reduced. However, the heterogeneous photo-Fenton reaction is rarely studied compared with other types of Fenton reactions, and thus deserves further investigations. To arouse the attention of readers regarding the importance of heterogeneous photo-Fenton reaction using the nanosized iron oxides for water treatment, this review starts with the brief development of the Fenton reaction, then has a special interest in the iron oxides as catalysts for the heterogeneous Fenton reaction, emphasizing the nanosized iron oxides including their preparation, associated Fenton matrix, and working mechanism. After that, the reusability of nanosized iron oxide and coupling of heterogeneous Fenton reaction with conventional water treatment technologies are addressed because the two topics are significant in real applications. Ahead of the concluding remarks, the potential environmental effect of nanoiron oxides is covered.

\section{Developments of the Fenton Reaction}

The classic Fenton process begins with the production of short-lived, extremely reactive $\cdot \mathrm{OH}$ with a potential of $2.8 \mathrm{~V}[1]$ from the interaction between $\mathrm{Fe}^{2+}$ and $\mathrm{H}_{2} \mathrm{O}_{2}$ (1). - $\mathrm{OH}$ then attacks the substrate, which results in substrate decomposition $[1,25]$.
- OH generation occurs with the concurrent transformation of $\mathrm{Fe}(\mathrm{II})$ to $\mathrm{Fe}(\mathrm{III})$, whose kinetics relies on the $\mathrm{pH}$, partial pressure of oxygen, and initial concentration of $\mathrm{Fe}^{2+}$, as expressed in the following equation [26]:

$$
\frac{d\left[\mathrm{Fe}^{2+}\right]}{d \mathrm{t}}=k\left[\mathrm{OH}^{-}\right]^{2} \mathrm{P}_{\mathrm{O}_{2}}\left[\mathrm{Fe}^{2+}\right]
$$

This indicates that the $\mathrm{pH}$ plays an important role in $\mathrm{Fe}$ (II) transformation, and a high $\mathrm{pH}$ favors $\mathrm{Fe}(\mathrm{II})$ oxidation. $\mathrm{pH}$ higher than 4.0 induces $\mathrm{Fe}(\mathrm{II})$ oxidation and its subsequent rapid precipitation, which adversely terminates the Fenton reaction. Therefore, the classic Fenton reaction is limited by a narrow $\mathrm{pH}$ range.

Under the narrow $\mathrm{pH}$ range, iron must be separated from water after use by adding alkali to form iron sludge, which is an awkward process in real applications. Thus, a heterogeneous Fenton reaction using solid iron oxides to extend the $\mathrm{pH}$ range and prevent the formation of iron sludge was needed.

The Fenton reaction is sustained by the redox recycling of the $\mathrm{Fe}(\mathrm{II}) / \mathrm{Fe}$ (III) couple, although $\mathrm{Fe}^{3+}$ can also initiate a Fenton-like reaction [27]. Equations (1) and (2) suggest that the reduction of $\mathrm{Fe}^{3+}$ to $\mathrm{Fe}^{2+}$ occurs much more slowly than the backward process. Thus, any measure to accelerate the $\mathrm{Fe}$ (II) regeneration is desired in the Fenton-based reaction. The phototreatment of solid iron oxides can accelerate the recycling of $\mathrm{Fe}(\mathrm{II}) / \mathrm{Fe}(\mathrm{III})$, as illustrated by [28]

$$
\mathrm{Fe}^{3+}+\mathrm{H}_{2} \mathrm{O}+h v \longrightarrow \mathrm{HO}^{\bullet}+\mathrm{Fe}^{2+}+\mathrm{H}^{+}
$$

Thus, the heterogeneous photo-Fenton reaction is established [29]. Given the difficult transportation and storage of $\mathrm{H}_{2} \mathrm{O}_{2}, \mathrm{H}_{2} \mathrm{O}_{2}$ is produced electrochemically instead of chemically. The in situ electrochemical production of $\mathrm{H}_{2} \mathrm{O}_{2}$ is performed via the cathodic reduction of oxygen from ambient air to establish the electro-Fenton reaction $[25,30-$ 34]:

$$
\mathrm{O}_{2}+2 e+2 \mathrm{H}^{+} \longrightarrow \mathrm{H}_{2} \mathrm{O}_{2}
$$

At the same time, the anodic reaction occurs to produce oxygen:

$$
\mathrm{H}_{2} \mathrm{O} \longrightarrow \frac{1}{2} \mathrm{O}_{2}+2 \mathrm{H}^{+}+2 e
$$

$\mathrm{H}^{+}$consumption (cathodic reaction) and production (anodic reaction) is an equilibrium process. Liu et al. [35] utilizes this inherent consumption and production of $\mathrm{H}^{+}$to adjust the $\mathrm{pH}$ automatically for the Fenton reaction instead of chemical addition.

Following the fundamental research of Fenton reaction, remarkable developments have been made to advance its application in water treatment $[13,26,36]$. A variety of Fenton reactions are outlined in Table 1.

Table 1 shows that the efforts exerted to develop the Fenton reaction focused on $\mathrm{pH}$ extension, in situ supply of $\mathrm{H}_{2} \mathrm{O}_{2}$ via the cathodic reduction of oxygen, in situ supply of $\mathrm{Fe}^{2+}$ via the electrochemical anodic oxidation of elemental iron, avoidance of iron loss, and $\mathrm{Fe}(\mathrm{II})$ regeneration by 
TABLE 1: Varieties of Fenton reactions.

\begin{tabular}{|c|c|c|c|c|}
\hline & Reagents & $\mathrm{pH}$ & $\begin{array}{l}\text { Iron } \\
\text { loss }\end{array}$ & Light \\
\hline Classic Fenton & $\mathrm{H}_{2} \mathrm{O}_{2}, \mathrm{Fe}^{2+}$ & $2-4$ & Yes & No \\
\hline Fenton-like & $\mathrm{H}_{2} \mathrm{O}_{2}, \mathrm{Fe}^{3+}$ & $2-4$ & Yes & No \\
\hline Photo-Fenton & $\begin{array}{l}\mathrm{H}_{2} \mathrm{O}_{2} \text {, iron } \\
\text { complex, free iron } \\
\text { ions }\end{array}$ & $\begin{array}{l}\text { Acidic to } \\
\text { neutral }\end{array}$ & Yes & Yes \\
\hline $\begin{array}{l}\text { Heterogeneous } \\
\text { Fenton }\end{array}$ & $\begin{array}{l}\mathrm{H}_{2} \mathrm{O}_{2} \text {, solid iron } \\
\text { oxide }\end{array}$ & Wide range & No & No \\
\hline Electro-Fenton & $\begin{array}{l}\text { Electrogenerated } \\
\mathrm{H}_{2} \mathrm{O}_{2} \text {, free iron } \\
\text { ions; } \\
\mathrm{H}_{2} \mathrm{O}_{2} \text {, } \\
\text { electrogenerated } \\
\mathrm{Fe}^{2+}\end{array}$ & $2-4$ & Yes & \\
\hline $\begin{array}{l}\text { Heterogeneous } \\
\text { photo-Fenton }\end{array}$ & $\begin{array}{l}\mathrm{H}_{2} \mathrm{O}_{2} \text {, solid iron } \\
\text { oxide }\end{array}$ & Wide range & No & Yes \\
\hline $\begin{array}{l}\text { Heterogeneous } \\
\text { photoelectro- } \\
\text { Fenton }\end{array}$ & $\begin{array}{l}\text { Electrogenerated } \\
\mathrm{H}_{2} \mathrm{O}_{2} \text {, solid iron } \\
\text { oxide }\end{array}$ & Wide range & No & Yes \\
\hline
\end{tabular}

illuminating the sludge iron sources [37]. Although all these modifications of the classic Fenton reaction cannot be coupled in one system, the heterogeneous photo-Fenton reaction unifies most of them and poses a promising Fentonbased technology. Obviously, it overcomes the $\mathrm{pH}$ limitation, prevents the iron loss after use like that in the reaction using free iron ions as the iron sources, and utilizes light to favor $\mathrm{Fe}(\mathrm{II})$ generation from $\mathrm{Fe}(\mathrm{III})$. The in situ supply of electrogenerated $\mathrm{H}_{2} \mathrm{O}_{2}$ can also be coupled into this system to form a photoelectro-Fenton system [31, 33]. Feoxalate can also be utilized in a heterogeneous photo-Fenton system by fixing the Fe ions on silica fabric [37]. Therefore, the heterogeneous photo-Fenton reaction covers almost all developments of the Fenton reaction and has certainly attracted much attention in recent years.

\section{Iron Oxides as Catalysts for the Heterogeneous Fenton Reaction}

Iron oxides are found abundantly in nature and easily synthesized in the laboratory. There are some iron oxides that exist in nature, hematite, magnetite $\left(\mathrm{Fe}_{3} \mathrm{O}_{4}\right)$, maghemite, $\beta-\mathrm{Fe}_{2} \mathrm{O}_{3}, \varepsilon-\mathrm{Fe}_{2} \mathrm{O}_{3}$, goethite, ferrihydrite, lepidocrocite, and wüstite $(\mathrm{FeO})$. Oxide-hydroxides can be dehydroxylated to their oxide counterparts under specific conditions such as thermal treatment. In most iron oxides, iron is present in the trivalent state, and three compounds of green rusts, magnetite, and wüstite contain Fe(II).

Although all iron oxides are crystalline, their degrees of structural order and crystallinities differ depending on the conditions for crystal formation. Ferrihydrite and schwetmannite are poorly crystalline. The structures of the iron oxides are well defined [38], and particularly interesting, determine the activities for the degradation of organic substrates.
Iron oxides are semiconductors. For instance, stoichiometric hematite is an n-type semiconductor, with the conduction band composed of empty $\mathrm{Fe}^{3+} \mathrm{d}$ orbitals and the valence band consisting of full $2 \mathrm{t}_{2 \mathrm{~g}}$ orbitals. Photocatalysts such as n-type $\mathrm{TiO}_{2}$ with a bandgap of $3.2 \mathrm{eV}$ that outputs holes and electrons upon UV excitation have been frequently investigated [39-41]. During the $\mathrm{TiO}_{2}$ photocatalytic process to decompose organic substrates, photogenerated holes can attack $\mathrm{H}_{2} \mathrm{O}$ molecules to produce $\bullet \mathrm{OH}$, which further oxidizes the organic substrates. Likewise, the bandgap of stoichiometric hematite is commonly considered to be $2.2 \mathrm{eV}$ [42]; thus, it can be photoexcited by light for the decomposition of organic pollutants in waters [43-45] and the splitting of $\mathrm{H}_{2} \mathrm{O}$ to extract hydrogen energy [46] or disinfect the water [47]. Apparently, poorly crystalline iron oxides release iron ions more readily than their good-crystalline counterparts particularly in acidic media.

\section{Nanosized Iron Oxides as Catalysts for the Heterogeneous Photo-Fenton Reaction}

Under sunlight irradiation, iron minerals are known to undergo reductive dissolution into $\mathrm{Fe}^{2+}$ species with the concomitant oxidation of organic compounds on solidliquid surfaces [48]. These heterogeneous photo-Fenton reactions with iron oxides as catalysts can be mimicked and applied in water treatment. Some mineral iron oxides such as $\mathrm{Fe}_{3} \mathrm{O}_{4}$ and $\mathrm{FeO}$ [49] have been reported to mediate the photo-Fenton reaction. To obtain desired properties, iron oxides are often prepared artificially; thus, extensive efforts have been exerted to the synthesis of iron oxides in the last decade.

Iron oxides are readily prepared using different methods, and their size, orientation, dimensionality, and morphology can be manipulated. Table 2 shows that, in recent years, various interesting architectures of nanoparticles, nanorods, nanoplates, nanosheets, and nanotubes for potential electronic, magnetic, optoelectronic, biomaterial, and catalytic applications have been developed. Nanoparticles have at least one dimension in size of less than $100 \mathrm{~nm}$, and the activity of solid catalysts depends on their particle size and fine structure. With decreased catalyst particle size to the nanometer scale, the particles exhibit unique catalytic activity due to their increased surface areas and number of active sites.

Nanoiron oxides have also been intensively fabricated, and the nanostructures of $\alpha-\mathrm{Fe}_{2} \mathrm{O}_{3}, \gamma-\mathrm{Fe}_{2} \mathrm{O}_{3}$, and $\mathrm{Fe}_{3} \mathrm{O}_{4}$ have attracted remarkable interest due to their potential applications in nanodevices. Among iron oxides, nanohematite is the most widely prepared probably because of its scientific and technological importance as the most stable iron oxide under ambient conditions. Several methods for hematite preparation are listed in Table 2.

For the large-scale production of nanoiron oxides, a low operational cost is highly expected. Generally, the hydrothermal method involves high pressure and temperature, and is thus an energy-intensive route. A method that utilizes a template or substrate to control direct growth often suffers from high cost, heterogeneous impurity, and complexity. For 
TABLE 2: Preparation methods of iron oxides.

\begin{tabular}{|c|c|c|c|}
\hline Nomenclature & Chemical & Preparation methods & Reference \\
\hline $\begin{array}{l}\text { Nanorod, } \\
\text { nanosphere, and } \\
\text { nanohexagon }\end{array}$ & $\alpha-\mathrm{Fe}_{2} \mathrm{O}_{3}$ & Hydrothermal & {$[50]$} \\
\hline Nanohematite & $\alpha-\mathrm{Fe}_{2} \mathrm{O}_{3}$ & Hydrothermal & {$[51,52]$} \\
\hline- & $\alpha-\mathrm{Fe}_{2} \mathrm{O}_{3}$ & Chemical precipitation & {$[53]$} \\
\hline - & - & $\begin{array}{l}\text { High-energy ball } \\
\text { milling }\end{array}$ & {$[54]$} \\
\hline Nanocomposite & $\mathrm{Fe}_{2} \mathrm{O}_{3} / \mathrm{SiO}_{2}$ & Sol-gel method & {$[16,55]$} \\
\hline $\begin{array}{l}\text { Maghemite } \\
(7-8 \mathrm{~nm})\end{array}$ & - & $\begin{array}{l}\text { Microemulsion } \\
\text { method }\end{array}$ & {$[56]$} \\
\hline $\mathrm{Fe} / \mathrm{SBA}-15$ & Hematite & $\begin{array}{l}\text { Two solvent } \\
\text { impregnation } \\
\text { technique }\end{array}$ & {$[57]$} \\
\hline \multirow{3}{*}{$\begin{array}{l}\text { Flower-like } \\
\text { hierarchical } \\
\alpha-\mathrm{Fe}_{2} \mathrm{O}_{3}\end{array}$} & $\alpha-\mathrm{Fe}_{2} \mathrm{O}_{3}$ & Solvent thermal & {$[45]$} \\
\hline & $\alpha-\mathrm{Fe}_{2} \mathrm{O}_{3}$ & Vapor-solid growth & {$[58]$} \\
\hline & $\alpha-\mathrm{Fe}_{2} \mathrm{O}_{3}$ & Solution-combustion & {$[59]$} \\
\hline $\begin{array}{l}\text { Flower-like } \\
\text { hematite }\end{array}$ & - & $\begin{array}{l}\text { Complexation- } \\
\text { mediated } \\
\text { oxidation-hydrolysis }\end{array}$ & {$[60]$} \\
\hline Nanocrystals & $\alpha-\mathrm{Fe}_{2} \mathrm{O}_{3}$ & $\begin{array}{l}\text { Convenient organic } \\
\text { phase process }\end{array}$ & {$[61]$} \\
\hline Nanoparticle & $\alpha-\mathrm{Fe}_{2} \mathrm{O}_{3}$ & $\begin{array}{l}\text { conducting controlled } \\
\text { oxidation reactions }\end{array}$ & {$[62]$} \\
\hline Nanocube & $\alpha-\mathrm{Fe}_{2} \mathrm{O}_{3}$ & - & {$[63]$} \\
\hline Nanospindle & $\alpha-\mathrm{Fe}_{2} \mathrm{O}_{3}$ & - & {$[64]$} \\
\hline Nanorod & $\alpha-\mathrm{Fe}_{2} \mathrm{O}_{3}$ & $\begin{array}{l}\text { Ethylenediamine- } \\
\text { (EDA-) assisted } \\
\text { method }\end{array}$ & {$[65,66]$} \\
\hline Nanowire & $\alpha-\mathrm{Fe}_{2} \mathrm{O}_{3}$ & Oxidation of pure iron & {$[67]$} \\
\hline Nanotube & - & $\begin{array}{l}\text { Solutionphase } \\
\text { approach }\end{array}$ & {$[52,68]$} \\
\hline Nanobelt & $\alpha-\mathrm{Fe}_{2} \mathrm{O}_{3}$ & $\begin{array}{l}\text { Direct thermal } \\
\text { oxidation }\end{array}$ & {$[69]$} \\
\hline Nanoflake & $\alpha-\mathrm{Fe}_{2} \mathrm{O}_{3}$ & Deposition & {$[70]$} \\
\hline
\end{tabular}

example, in hematite nanotube preparation using an $\mathrm{Al}_{2} \mathrm{O}_{3}$ anodic membrane, the hard template needs to be removed by chemical etching in aqueous $\mathrm{NaOH}$, an extremely basic solution [68].

To overcome the disadvantages of the conventional hydrothermal and template methods for the synthesis of nanosized iron oxides, Zhou and Wong [71] reported a facile synthesis of $\alpha-\mathrm{Fe}_{2} \mathrm{O}_{3}$ hierarchical nanoarchitectures by a solvent thermal process (isopropyl alcohol-mediated selfassembly) without any template or matrix. The formation of 3D porous flower-like $\alpha-\mathrm{Fe}_{2} \mathrm{O}_{3}$ involves a few sequential steps, including nucleation and aggregation, secondary growth (self-assembly), further growth (also self-assembly), and Ostwald ripening (coarsening) [45]. Similarly, Wang et al. [72] prepared flower-like porous hematite nanoarchitectures by annealing the iron oxide precursor formed via the oxidation-hydrolysis reaction between $\mathrm{Fe}(\mathrm{II})$ ions and Tris(hydroxymethyl) aminomethane (Tris). They proposed a formation mechanism of "complex-assembly-aggregationetching," wherein as-prepared flower-like nanostructures are nucleated by the self-assembly of Fe(II)-Tris complexes via hydrogen bonds. A simple solution-combusting method to prepare nano- $\alpha-\mathrm{Fe}_{2} \mathrm{O}_{3}$ particles has been reported. Using a mixture solvent of ethanol and ethyleneglycol, $\mathrm{FeCl}_{3}$ as iron source, and atmospheric oxygen gas as oxidant, nano$\alpha-\mathrm{Fe}_{2} \mathrm{O}_{3}$ particles can be rapidly obtained in one step. This method is cost effective, safe, easily reproducible, and high yielding [72].

Aside from one-component iron oxides, iron oxides with two or more components can be prepared [12] with each component having its specialized function. The composite iron oxides exhibits unique chemical and physical properties.

Chemically, the combination of two oxides exerts a synergistic effect that outweighs the sum of the effects of all individual components. Mazille et al. $[73,74]$ prepared polymer films that contain titanium oxide and iron oxide $\left(\mathrm{PVF}^{\mathrm{f}}\right.$ $\mathrm{TiO}_{2}-\mathrm{Fe}$ ). Experiments on the photocatalytic degradation of a few organic substrates (e.g., phenol, nalidixic acid, pesticide mixtures, etc.) demonstrated that the composite oxides have synergistic photocatatalytic activity at neutral $\mathrm{pH}$. The high activity is attributed to the photo-Fenton reaction (10) and photocatalytic reaction (11) occurring both on the iron oxide and $\mathrm{TiO}_{2}$ surfaces. In particular, the synergistic activity (12) between the two components is believed to accelerate $\mathrm{Fe}$ (II) regeneration, which is the rate-determining step in the Fenton reaction [75]. The simplified mechanism can be outlined as follows:

$$
\begin{gathered}
=\mathrm{Fe}(\mathrm{III})+\mathrm{H}_{2} \mathrm{O}_{2} \longrightarrow=\mathrm{Fe}(\mathrm{II})+\mathrm{H}^{+}+\mathrm{HO}_{2} \cdot \\
=\mathrm{Fe}(\mathrm{II})+\mathrm{H}_{2} \mathrm{O}_{2} \longrightarrow=\mathrm{Fe}(\mathrm{III})+\mathrm{OH}^{-}+\mathrm{OH}^{\bullet} \\
=\mathrm{Fe}(\mathrm{III}) L_{n}+h v \longrightarrow=\mathrm{Fe}(\mathrm{II}) L_{n-1}+L_{o x}^{\bullet+} \\
\mathrm{Fe} \text { oxide }+h v \longrightarrow \mathrm{Fe} \text { oxide }\left(\mathrm{e}^{-}+\mathrm{h}^{+}\right) \\
\mathrm{TiO}_{2}+h v \longrightarrow \mathrm{TiO}_{2}\left(\mathrm{e}^{-}+\mathrm{h}^{+}\right) \\
=\mathrm{Fe}(\mathrm{III})+h v+\mathrm{TiO}_{2} \longrightarrow=\mathrm{Fe}(\mathrm{IV})+\mathrm{TiO}_{2}\left(\mathrm{e}^{-}\right)
\end{gathered}
$$$$
\text { Fe oxide }+\mathrm{TiO}_{2} \longrightarrow \text { Fe oxide }\left(e^{-}\right)+\mathrm{TiO}_{2}
$$

Fe oxide $\left(\mathrm{e}^{-}\right)+=\mathrm{Fe}(\mathrm{III}) \longrightarrow$ Fe oxide $+=\mathrm{Fe}(\mathrm{II})$

In all the above equations, $=\mathrm{Fe}(\mathrm{II})$ and $=\mathrm{Fe}(\mathrm{III})$ are iron species in the solid phase or at the solid-liquid interface.

In some circumstances, the cocomponent assists the immobilization and dispersion of fine particles of iron oxides, which are not trivial tasks. Rasoulifarda et al. [76] prepared nanosized $\mathrm{Fe}_{2} \mathrm{O}_{3} / \mathrm{SiO}_{2}$ composites by the sol-gel method and calcination. $\mathrm{Fe}_{2} \mathrm{O}_{3}$ induces the photo-Fenton decolorization of azo dye from contaminated water, and $\mathrm{SiO}_{2}$ immobilizes the iron oxides. Ho et al. [77] applied solid waste comprising iron oxides that is immobilized on $\mathrm{SiO}_{2}$ in the photo-Fenton degradation of reactive black $\mathrm{B}$ in a fluidized reactor. $\mathrm{SiO}_{2}$ also ensures the recovery of the catalyst with continued activity after three successive tests. Chhabra et al. [51] used a single SBA-15 silica with a mesopore diameter of $7.1 \mathrm{~nm}$ and two solvent impregnation techniques to 
deposit the iron ions into silica pores. Interesting, a spatial location of the iron oxides are observed to be trapped inside the silica pores or dispersed outside silica grains. The external hematite particles are significantly less active and react less rapidly than the internally trapped iron species in the photoFenton decomposition. Wang et al. [78] observed that, the dispersion of $\alpha-\mathrm{Fe}_{2} \mathrm{O}_{3}$ on silica minimizes particle growth during the sintering process. $\mathrm{Fe}_{2} \mathrm{O}_{3}$ crystallites also have larger surface areas and smaller sizes of around $8 \mathrm{~nm}$ than unsupported $\mathrm{Fe}_{2} \mathrm{O}_{3}$ (>30 nm). They also observed through $\mathrm{X}$-ray diffraction that the phase transformation from $\beta$ $\mathrm{FeOOH}$ to $\alpha-\mathrm{Fe}_{2} \mathrm{O}_{3}$ upon thermal treatment is inhibited on silica. In the presence of silica, newly formed ferric (hydr)oxides via photodissolution are preferably redeposited onto the silica instead of $\alpha-\mathrm{Fe}_{2} \mathrm{O}_{3}$ due to the negatively charged surface. Ferric (hydr)oxides are mostly amorphous and less photoactive; thus, $\alpha-\mathrm{Fe}_{2} \mathrm{O}_{3} / \mathrm{SiO}_{2}$ is more photoactive than $\alpha-\mathrm{Fe}_{2} \mathrm{O}_{3}$.

Another type of two-component iron oxide is formed by the modification of iron oxides using a metal such as gold. Gao et al. [46] described an $\mathrm{Au} / \mathrm{Fe}_{2} \mathrm{O}_{3}$ aerogel for the photodegradation of azo dye. Due to the addition of gold species to the $\mathrm{Fe}_{2} \mathrm{O}_{3}$, the light absorption spectrum shifts toward the red visible region and reduces the band gap energy. Accordingly, enhanced photocatalytic activity is obtained.

Sometimes, coexisting organic substance, such as organic acids, especially oxalic acid, serves as an indispensable component of the heterogeneous Fenton reaction. The organic acid interacts with the iron oxide under the excitation of photoenergy to produce s serials of radicals including hydroxyl radicals, and then the target substrates are decomposed [7981].

\section{Reuse of NanoIron Oxides}

In the photo-Fenton process, the use of $\mathrm{Fe}(\mathrm{II}) / \mathrm{Fe}(\mathrm{III})$ as a homogeneous catalyst suffers from a major disadvantage, that is, the need to remove the iron sludge after water treatment. This drawback can be overcome by solid iron oxides. The development of nanosized iron oxides increases their activity in the heterogeneous photo-Fenton reaction, whereas the fine particles of nanosized iron oxides necessitate catalyst reusability. The process of separating nanosized particles from the aqueous phase after the reactions is also complicated [82].

For easy separation, magnetic iron oxides [83] that can settle at the bottom of a reactor by the aid of a magnetic field placed under the reactor have been designed. Obviously, this separation method is limited to iron oxides with magnetic force. For other types of nanosized iron oxides without magnetic force, the separation of fine particles from aqueous solution must resort to an alternative technology.

A simple and effective alternative to the prevention of runoff of nanosized catalysts is the immobilization of fine particles on a support. There are various available materials that can serve as supports, such as silica [77, 84, 85], polymer [86, 87], SBA [57], zeolitic Fe(III)-Y and Fe(II)-3X materials [88], alumina [89], and pillared clays [90].
Once immobilized onto support materials, the associated catalytic efficiency may decrease even if there is a synergetic effect. Generally, nanosized iron oxides in powder form can ensure fine contact between light and iron oxide particles. The illumination of the iron oxide surface is a prerequisite for $\mathrm{Fe}(\mathrm{II}) / \mathrm{Fe}$ (III) recycling to sustain the Fenton reaction. Unfortunately, after the particles of iron oxides are immobilized onto a support, particularly onto a porous one, adequate illumination enjoyed by a naked particle system, may be impeded. To date, whether such illumination loss actually occurs is not known.

In $\mathrm{TiO}_{2}$ photocatalysis, $\mathrm{Li}$ et al. [82] reported a type of $\mathrm{TiO}_{2}$ microspheres fabricated from $\mathrm{TiO}_{2}$-nanosized particles and their sol precursor. They observed that the microspheres possess larger pore volumes and surface areas, and consequently, comparable activity with the nanosized particle counterpart. Microspheres with sizes of 30-160 $\mu \mathrm{m}$ can also be suspended readily by air bubbling to ensure sufficient illumination. These microspheres can settle quickly at the bottom of the reactor when the air supply stops after use for easy separation from the aqueous solution and reuse. This design concept also appears to be applicable in the heterogeneous photo-Fenton system with nanosized iron oxides.

On the other hand, support materials sometimes have adverse effects on the photo-Fenton reaction. For example, after the support of iron oxides on zeolite, the iron exchange of iron species within the zeolite framework slows down and the stability decreases compared with those in unsupported iron oxides, and some supports such as Nafion are very costly because perfluorosulphonic polymer is used [91]. Thus, its large-scale application in water treatment is hindered.

\section{Coupling of Iron Oxide-Based Heterogeneous Photo-Fenton Technology with an Integrated Process of Water Treatment}

Effluents discharged from industrial processes usually contain recalcitrant pollutants that are nonbiodegradable and destroyed only by chemical approaches. Fenton-based processes are highly effective chemical means that offer simple and cost-effective sources of $\cdot \mathrm{OH}$ to decompose recalcitrant pollutants [92-94]. The heterogeneous photo-Fenton reaction addresses the drawbacks that arise from the classic Fenton reaction, and it is a promising chemical technology for destroying and mineralizing recalcitrant pollutants. Following the successful development of the heterogeneous photo-Fenton technology with iron oxides as catalyst, an incorporation of this technology into an overall process for water treatment becomes essential, given that any individual technology has its own inherent disadvantages and compatible conditions. Water purification demands the coupling of diverse technologies to achieve an integrated process.

Technically, the heterogeneous photo-Fenton process is applicable when two prerequisites are satisfied. One is the transparency of water that ensures the transmission of light. The other is the nonbiodegradability of water that has to be treated by the abiotic method. This method is expected to 
improve the biodegradability of water as a pretreatment unit or to decompose recalcitrant pollutants as an advanced unit.

Along with the heterogeneous photo-Fenton process are conventional technologies that work together to purify the polluted influent. At the front-end of the integrated process, the influent can be pretreated by a physical unit such as filtration or grilling to separate the solids present in it. A physicochemical process such as coagulation is subsequently performed to remove colloidal substances. A biological process such as aerobic or anaerobic oxidation is performed to degrade most of the biodegradable organic molecules. Thus, the water quality is usually improved in terms of indices such as chemical oxygen demand (COD) and $\mathrm{NH}_{3}$ $\mathrm{N}$. If the effluent requires further purification to destroy nondegradable organic pollutants, the heterogeneous photoFenton technology follows the biological process. Advanced treatment is believed to increasingly important with the increased requirement of wastewater reclamation.

Alternatively, heterogeneous photo-Fenton technology is used prior to the biochemical process to improve biodegradability for better biological oxidization of the organic substrates in the subsequent process. In this regard, the organic pollutants are highly toxic to the biotas; thus, they are decomposed by the heterogeneous photo-Fenton technology [91].

If the heterogeneous photo-Fenton process is followed by another process, further measures must be taken in some cases. For example, if there is $\mathrm{H}_{2} \mathrm{O}_{2}$ residue (even in small amounts) in the effluent and a membrane process follows for further treatment, the residual $\mathrm{H}_{2} \mathrm{O}_{2}$ must be decomposed to protect the membrane from oxidation.

The smart coupling of the heterogeneous photo-Fenton technology with conventional technologies results in an integrated process for water treatment. The enhanced degradation of polycyclic aromatic hydrocarbons by biodegradation combined with a modified Fenton's reaction [95] is expected to have progress based on a comprehensive assessment of technique and economic feasibility. A pilotscale test is extremely necessary to verify such data because related reports are very limited.

\section{Potential Environmental Effect of Nanoiron Oxides}

Nanoparticles are increasingly used for industrial and commercial purposes due to their unique characteristics, such as large specific surface areas and unique surface structures that cause high surface reactivity. The widespread use of nanoparticles leads to their inevitable release into the environment during manufacturing, transportation, use, and/or disposal. Therefore, the potential health and environmental risks posed by nanoparticles have drawn significant attention in recent years [96]. In aqueous environments, many nanoparticles such as nano- $\mathrm{TiO}_{2}[97,98]$ and nano- $\mathrm{Al}_{2} \mathrm{O}_{3}$ have been confirmed to pose biological risks. Consequently, the bioaccumulation of nanoparticles in aquatic organisms is a very important process that affects the overall toxicity of nanoparticles in a realistic environment.
Iron oxides are commonly considered to be nontoxic, whereas some studies suggest that C. dubia significantly accumulate on nano- $\mathrm{Fe}_{2} \mathrm{O}_{3}$ through ingestion and that nano- $\mathrm{Fe}_{2} \mathrm{O}_{3}$ serves as a carrier of $\mathrm{As}(\mathrm{V})$ to enhance $\mathrm{As}(\mathrm{V})$ toxicity [99]. Some studies reported the cytotoxicity of nano$\mathrm{Fe}_{2} \mathrm{O}_{3}$ toward different types of cell lines, such as human MSTO cells [100] and PC12 cells [101], or toward different bacteria, such as Escherichia coli [102]. Katsnelson et al. also observed that at equal mass doses, $\mathrm{Fe}_{3} \mathrm{O}_{4}$ nanoparticles possess considerably higher systemic toxicity than microparticles [103].

Nanoiron oxides can also be formed via secondary formation. For example, nanoscale zerovalent iron that is often used for groundwater remediation because of its reducing ability can be oxidized over time to magnetite, maghemite, hematite, and goethite. Such surface oxidation tends to reduce the activity, agglomeration, sedimentation rate, and toxicity to mammalian cells [104].

Primary tests on the toxicity of nanoiron oxides indicate that great care must be taken when handling nanosized iron oxides during their life cycle from manufacturing to disposal. When used in water treatment, nanoiron oxides can be reused by gravity-induced settlement and immobilization onto a support material that enables their fast separation. Although long-term utilization is possible under illumination, the nanoparticles may undergo photocorrosion and escape from the system into the aquatic environment. In this case, further efforts are recommended to improve the photostability of the iron oxides for the heterogeneous photo-Fenton reaction.

\section{Concluding Remarks}

The heterogeneous photo-Fenton reaction combines most efforts to overcome the drawbacks of the classic Fenton reaction. This combination extends the working $\mathrm{pH}$ range using a solid iron source instead of free iron ions. The method also prevents the formation of iron sludge by immobilizing iron oxides, accelerates Fe(II) regeneration by light illumination, and enables the reusability of iron oxides after separation by rapid settlement. The preparation and utilization of nanosized iron oxides pave the way for technological advancement by allowing the manipulation of their architectures and chemical compositions. Consequently, unique physical and chemical properties are exhibited by these nanoiron oxides.

Following the successful development of the heterogeneous photo-Fenton process, a smart coupling of this technology with conventional ones such as filtration, coagulation, biological oxidation, and membrane technology becomes essential. Thus, pilot-scale and field tests are necessary to develop a well-established integrated water treatment process that involves the heterogeneous photoFenton reaction and determine technical and economical parameters.

Research on the heterogeneous photo-Fenton process is expected to grow rapidly in the near future prompted by the increasing amount of released recalcitrant pollutants. Future investigations may center on the fabrication of finer physical architectures and well-defined chemical compositions of 
nanosized irons oxides. The degradation pathway of organic substrates and evolution of toxicity during the treatment process should be determined. Attention must also be paid to the potential environmental effect of nanosized iron oxides. The mechanism that governs the catalytic reactions occurring on the surface or in the pores of nanosized iron oxides remains to be elucidated as well.

\section{Acknowledgment}

This work was supported by the Natural Science Foundation of China (Project nos. 21077071, 50978260, and 51178129) and Chongqing Science \& Technology Commission (no. CSTC 2ZR11HD030).

\section{References}

[1] E. Neyens and J. Baeyens, "A review of classic Fenton's peroxidation as an advanced oxidation technique," Journal of Hazardous Materials, vol. 98, no. 1-3, pp. 33-50, 2003.

[2] J. J. Pignatello, "Dark and photoassisted $\mathrm{Fe}^{3+}$-catalyzed degradation of chlorophenoxy herbicides by hydrogen peroxide," Environmental Science \& Technology, vol. 26, no. 5, pp. 944-951, 1992.

[3] Y. Sun and J. J. Pignatello, "Photochemical reactions involved in the total mineralization of $2,4-\mathrm{D}$ by $\mathrm{Fe}^{3+} / \mathrm{H}_{2} \mathrm{O}_{2} / \mathrm{UV}$," Environmental Science \& Technology, vol. 27, no. 2, pp. 304310, 1993.

[4] N. Miguel, M. P. Ormad, R. Mosteo, and J. L. Ovelleiro, "Photocatalytic degradation of pesticides in natural water: effect of hydrogen peroxide," International Journal of Photoenergy, vol. 2012, Article ID 371714, 11 pages, 2012.

[5] F. Z. Shi, Y. G. Li, Q. H. Zhang, and H. Z. Wang, "Synthesis of $\mathrm{Fe}_{3} \mathrm{O}_{4} / \mathrm{C} / \mathrm{TiO}_{2}$ magnetic photocatalyst via vapor phase hydrolysis," International Journal of Photoenergy, vol. 2012, Article ID 365401, 8 pages, 2012.

[6] J. De Laat, T. G. Le, and B. Legube, "A comparative study of the effects of chloride, sulfate and nitrate ions on the rates of decomposition of $\mathrm{H}_{2} \mathrm{O}_{2}$ and organic compounds by $\mathrm{Fe}(\mathrm{II}) / \mathrm{H}_{2} \mathrm{O}_{2}$ and $\mathrm{Fe}(\mathrm{III}) / \mathrm{H}_{2} \mathrm{O}_{2}$," Chemosphere, vol. 55, no. 5, pp. 715-723, 2004.

[7] J. D. Laat and T. G. Le, "Kinetics and modeling of the $\mathrm{Fe}(\mathrm{III}) / \mathrm{H}_{2} \mathrm{O}_{2}$ system in the presence of sulfate in acidic aqueous solutions," Environmental Science \& Technology, vol. 39, no. 6, pp. 1811-1818, 2005.

[8] B. Ensing, F. Buda, and E. J. Baerends, "Fenton-like chemistry in water: oxidation catalysis by $\mathrm{Fe}(\mathrm{III})$ and $\mathrm{H}_{2} \mathrm{O}_{2}$," Journal of Physical Chemistry A, vol. 107, no. 30, pp. 5722-5731, 2003.

[9] H. Zhang, D. Zhang, and J. Zhou, "Removal of COD from landfill leachate by electro-fenton method," Journal of Hazardous Materials, vol. 135, no. 1-3, pp. 106-111, 2006.

[10] H. Zhang, H. J. Choi, and C. P. Huang, "Optimization of Fenton process for the treatment of landfill leachate," Journal of Hazardous Materials, vol. 125, no. 1-3, pp. 166-174, 2005.

[11] M. M. Cheng, W. H. Ma, J. Li et al., "Visible-light-assisted degradation of dye pollutants over $\mathrm{Fe}(\mathrm{III})$-loaded resin in the presence of $\mathrm{H}_{2} \mathrm{O}_{2}$ at neutral $\mathrm{pH}$ values," Environmental Science \& Technology, vol. 38, no. 5, pp. 1569-1575, 2004.

[12] X. L. Liang, Y. H. Zhong, S. Y. Zhu et al., "The contribution of vanadium and titanium on improving methylene blue decolorization through heterogeneous UV-Fenton reaction catalyzed by their co-doped magnetite," Journal of Hazardous Materials, vol. 199-200, pp. 247-254, 2012.
[13] C. Cornu, J. L. Bonardet, S. Casale et al., "Identification and location of iron species in Fe/SBA-15 catalysts: interest for catalytic Fenton reaction," Journal of Physical Chemistry C, vol. 116, no. 5, pp. 3437-3448, 2012.

[14] M. Fang, T. V. Volotinen, S. K. Kulkarni, L. Belova, and K. V. Rao, "Effect of embedding $\mathrm{Fe}_{3} \mathrm{O}_{4}$ nanoparticles in silica spheres on the optical transmission properties of threedimensional magnetic photonic crystals," Journal of Applied Physics, vol. 108, no. 10, Article ID 103501, 6 pages, 2010.

[15] S. P. Sun and A. T. Lemley, " $p$-nitrophenol degradation by a heterogeneous Fenton-like reaction on nano-magnetite: process optimization, kinetics, and degradation pathways," Journal Molecular Catatalysis A, vol. 349, no. 1-2, pp. 71-79, 2011.

[16] M. H. Rasoulifard, M. H. Hosseini, and S. Masoudian, "Photo-assisted hetero-Fenton decolorization of azo dye from contaminated water by Fe-Si mixed oxide nanocomposite," Environmental Technology, vol. 32, no. 14, pp. 16271635, 2011.

[17] E. G. Garrido-Ramírez, B. K. G. Theng, and M. L. Mora, "Clays and oxide minerals as catalysts and nanocatalysts in Fenton-like reactions-a review," Applied Clay Science, vol. 47, no. 3-4, pp. 182-192, 2010.

[18] F. Martínez, G. Calleja, J. A. Melero, and R. Molina, "Heterogeneous photo-Fenton degradation of phenolic aqueous solutions over iron-containing SBA-15 catalyst," Applied Catalysis B, vol. 60, no. 3-4, pp. 181-190, 2005.

[19] A. Jitianu, M. Crisan, A. Meghea, I. Rau, and M. Zaharescu, "Influence of the silica based matrix on the formation of iron oxide nanoparticles in the $\mathrm{Fe}_{2} \mathrm{O}_{3}-\mathrm{SiO}_{2}$ system, obtained by sol-gel method," Journal of Materials Chemistry, vol. 12, no. 5, pp. 1401-1407, 2002.

[20] Q. Han, S. Y. Yang, X. Yang et al., "Cobalt catalyzed peroxymonosulfate oxidation: a review of mechanisms and applications on degradating organic pollutants in water," Progress in Chemistry, vol. 24, no. 1, pp. 144-156, 2012.

[21] G. Q. Zhang, S. Wang, and F. L. Yang, "Efficient adsorption and combined heterogeneous/homogeneous Fenton oxidation of amaranth using supported nano-FeOOH as cathodic catalysts," Journal of Physical Chemistry C, vol. 116, no. 5, pp. 3623-3634, 2012.

[22] F. Yuan, C. Hu, X. X. Hu, D. Wei, Y. Chen, and J. Qu, "Photodegradation and toxicity changes of antibiotics in UV and UV/ $\mathrm{H}_{2} \mathrm{O}_{2}$ process," Journal of Hazardous Materials, vol. 185, no. 2-3, pp. 1256-1263, 2011.

[23] M. S. Lucas, J. A. Peres, and P. G. Li, "Treatment of winery wastewater by ozone-based advanced oxidation processes $\left(\mathrm{O}_{3}, \mathrm{O}_{3}\right.$ and $\left.\mathrm{O}_{3} / \mathrm{UV} / \mathrm{H}_{2} \mathrm{O}_{2}\right)$ in a pilot-scale bubble column reactor and process economics," Separation and Purification Technology, vol. 72, no. 3, pp. 235-241, 2010.

[24] M. Muneer, I. A. Bhatti, E. Ehsan-Ul-Haq, M. Safdar, and F. Fazal-Ur-Rehman, "Applications of advanced oxidation process for industrial wastewater treatment," Asian Journal of Chemistry, vol. 22, no. 4, pp. 3087-3093, 2010.

[25] E. Brillas, I. Sirés, and M. A. Oturan, "Electro-fenton process and related electrochemical technologies based on Fenton's reaction chemistry," Chemical Reviews, vol. 109, no. 12, pp. 6570-6631, 2009.

[26] W. Sung and J. J. Morgan, "Kinetics and product of ferrous iron oxygenation in aqueous systems," Environmental Science \& Technology, vol. 14, no. 5, pp. 561-568, 1980.

[27] H. D. Basheer, A. A. R. Abdul, and D. W. M. A. Wan, "Oxidative mineralisation of petroleum refinery effluent 
using Fenton-like process," Chemical Engineering Research and Design, vol. 90, no. 2, pp. 298-307, 2012.

[28] K. S. Mihir, "Degradation and mineralization, of organic contaminants by Fenton and photo-Fenton processes: review of mechanisms and effects of organic and inorganic additives," Research Journal of Chemistry and Environment, vol. 15, no. 2, pp. 96-112, 2011.

[29] C. Cezar, A. Daniela, and A. Petru, "Degradation of 4chlorophenol from wastewater through heterogeneous Fenton and photo-Fenton process, catalyzed by Al-Fe PILC," Applied Clay Science, vol. 58, pp. 96-101, 2012.

[30] E. Brillas, R. Sauleda, and J. Casado, "Degradation of 4-chlorophenol by anodic oxidation, electro-fenton, photoelectro-fenton, and peroxi-coagulation processes," Journal of the Electrochemical Society, vol. 145, no. 3, pp. 759765, 1998.

[31] B. Boye, M. M. Dieng, and E. Brillas, "Degradation of herbicide 4-chlorophenoxyacetic acid by advanced electrochemical oxidation methods," Environmental Science \& Technology, vol. 36, no. 13, pp. 3030-3035, 2002.

[32] E. Brillas and J. Casado, "Aniline degradation by electroFenton and peroxi-coagulation processes using a flow reactor for wastewater treatment," Chemosphere, vol. 47, no. 3, pp. 241-248, 2002.

[33] E. Brillas, M. A. Baños, and J. A. Garrido, "Mineralization of herbicide 3,6-dichloro-2-methoxybenzoic acid in aqueous medium by anodic oxidation, electro-Fenton and photoelectro-Fenton," Electrochimica Acta, vol. 48, no. 12, pp. 1697-1705, 2003.

[34] E. Brillas, J. C. Calpe, and J. Casado, "Mineralization of 2,4D by advanced electrochemical oxidation processes," Water Research, vol. 34, no. 8, pp. 2253-2262, 2000.

[35] H. Liu, C. Wang, X. Z. Li, X. L. Xuan, C. Jiang, and H. N. Cui, "A novel electro-Fenton process for water treatment: reaction-controlled $\mathrm{pH}$ adjustment and performance assessment," Environmental Science \& Technology, vol. 41, no. 8, pp. 2937-2942, 2007.

[36] C. Walling, "Fenton's reagent revisited," Accounts of Chemical Research, vol. 8, no. 4, pp. 125-131, 1975.

[37] A. Bozzi, T. Yuranova, J. Mielczarski, and J. Kiwi, "Evidence for immobilized photo-Fenton degradation of organic compounds on structured silica surfaces involving Fe recycling," New Journal of Chemistry, vol. 28, no. 4, pp. 519-526, 2004.

[38] R. M. Cornell and U. Schwertmann, The Iron Oxides, Willy, 2003.

[39] Q. J. Xiang, J. G. Yu, and P. K. Wong, "Quantitative characterization of hydroxyl radicals produced by various photocatalysts," Journal of Colloid and Interface Science, vol. 357, no. 1, pp. 163-167, 2011.

[40] X. X. Yu, S. W. Liu, and J. G. Yu, "Superparamagnetic $\gamma$ $\mathrm{Fe}_{2} \mathrm{O}_{3} @ \mathrm{SiO}_{2} @ \mathrm{TiO}_{2}$ composite microspheres with superior photocatalytic properties," Applied Catalysis B, vol. 104, no. 1-2, pp. 12-20, 2011.

[41] T. X. Liu, Y. Liu, Z. J. Zhang, F. B. Li, and X. Z. Li, "Comparison of aqueous photoreactions with $\mathrm{TiO}_{2}$ in its hydrosol solution and powdery suspension for light utilization," Industrial \& Engineering Chemistry Research, vol. 50, no. 13, pp. 7841-7848, 2011.

[42] A. Kay, I. Cesar, and M. Grätzel, "New benchmark for water photooxidation by nanostructured $\alpha-\mathrm{Fe}_{2} \mathrm{O}_{3}$ films," Journal of the American Chemical Society, vol. 128, no. 49, pp. 1571415721, 2006.
[43] S. K. Maji, N. Mukherjee, A. Mondal, and B. Adhikary, "Synthesis, characterization and photocatalytic activity of $\alpha$ $\mathrm{Fe}_{2} \mathrm{O}_{3}$ nanoparticles," Polyhedron, vol. 33, no. 1, pp. 145-149, 2012.

[44] S. Hu, G. L. Liu, D. W. Zhu, C. Chen, and S. Liao, "Synthesis, characterization, and evaluation of boron-doped iron oxides for the photocatalytic degradation of atrazine under visible light," International Journal of Photoenergy, vol. 2012, Article ID 598713, 4 pages, 2012.

[45] L. P. Zhu, N. C. Bing, L. L. Wang et al., "Self-assembled 3D porous flowerlike $\alpha-\mathrm{Fe}_{2} \mathrm{O}_{3}$ hierarchical nanostructures: synthesis, growth mechanism, and their application in photocatalysis," Dalton Transaction, vol. 2012, no. 41, pp. 2959-2965, 2012.

[46] H. W. Gao, C. Liu, H. E. Jeong, and P. D. Yang, "Plasmonenhanced photocatalytic activity of iron oxide on gold nanopillars," ACS Nano, vol. 6, no. 1, pp. 234-240, 2012.

[47] J. A. Byrne, P. A. Fernandez-Ibanez, P. S. M. Dunlop, D. M. A. Alrousan, and J. W. J. Hamilton, "Photocatalytic enhancement for solar disinfection of water: a review," International Journal of Photoenergy, vol. 2011, Article ID 798051, 12 pages, 2011.

[48] U. Schwertmann and R. M. Cornell, Iron Oxides in the Laboratory: Preparation and Characterization, John Wiley \& Sons, 2008.

[49] E. Expósito, C. M. Sánchez-Sánchez, and V. Montiel, "Mineral iron oxides as iron source in electro-fenton and photoelectro-fenton mineralization processes," Journal of the Electrochemical Society, vol. 154, no. 8, pp. E116-E122, 2007.

[50] G. K. Pradhan and K. M. Parida, "Fabrication, growth mechanism, and characterization of $\alpha-\mathrm{Fe}_{2} \mathrm{O}_{3}$ nanorods," ACS Applied Materials \& Interfaces, vol. 3, no. 2, pp. 317-323, 2011.

[51] V. Chhabra, P. Ayyub, S. Chattopadhyay, and A. N. Maitra, "Preparation of acicular $\gamma-\mathrm{Fe}_{2} \mathrm{O}_{3}$ particles from a microemulsion-mediated reaction," Materials Letters, vol. 26, no. 1-2, pp. 21-26, 1996.

[52] C. J. Jia, L. D. Sun, Z. G. Yan et al., "Single-crystalline iron oxide nanotubes," Angewandte Chemie, vol. 44, no. 28, pp. 4328-4333, 2005.

[53] X. Q. Su and B. Yan, "The synthesis and luminescence of $\mathrm{YP}_{x} \mathrm{~V}_{1-x} \mathrm{O}_{4}: \mathrm{Dy}^{3+}$ microcrystalline phosphors by in situ coprecipitation composition of hybrid precursors," Materials Chemistry and Physics, vol. 93, no. 2-3, pp. 552-556, 2005.

[54] Y. H. Ni, X. F. Cao, G. G. Wu, G. Hu, Z. Yang, and X. Wei, "Preparation, characterization and property study of zinc oxide nanoparticles via a simple solution-combusting method," Nanotechnology, vol. 18, no. 15, Article ID 155603, 2007.

[55] X. Wang, X. Y. Chen, L. S. Gao et al., "Synthesis of $\beta-\mathrm{FeOOH}$ and $\alpha-\mathrm{Fe}_{2} \mathrm{O}_{3}$ nanorods and electrochemical properties of $\beta$ FeOOH," Journal of Materials Chemistry, vol. 14, no. 5, pp. 905-907, 2004.

[56] Z. M. Li, X. Y. Lai, H. Wang, D. Mao, C. Xing, and D. Wang, "Direct hydrothermal synthesis of single-crystalline hematite nanorods assisted by 1,2-propanediamine," Nanotechnology, vol. 20, no. 24, Article ID 245603, 2009.

[57] C. Cornu, J. L. Bonardet, S. Casale et al., "Identification and location of iron species in Fe/SBA-15 catalysts: interest for catalytic Fenton reactions," Journal of Physical Chemistry C, vol. 116, pp. 3437-3448, 2012.

[58] Y. Y. Fu, R. M. Wang, J. Xu et al., "Synthesis of large arrays 
of aligned $\alpha-\mathrm{Fe}_{2} \mathrm{O}_{3}$ nanowires," Chemical Physics Letters, vol. 379, no. 3-4, pp. 373-379, 2003.

[59] X. H. Wang, L. Zhang, Y. H. Ni, J. Hong, and X. Cao, "Fast preparation, characterization, and property study of $\alpha-\mathrm{Fe}_{2} \mathrm{O}_{3}$ nanoparticles via a simple solution-combusting method," Journal of Physical Chemistry C, vol. 113, no. 17, pp. 70037008, 2009.

[60] X. Huang, J. G. Guan, Z. D. Xiao, G. Tong, F. Mou, and X. Fan, "Flower-like porous hematite nanoarchitectures achieved by complexation-mediated oxidation-hydrolysis reaction," Journal of Colloid and Interface Science, vol. 357, no. 1, pp. 36-45, 2011.

[61] S. Sun, H. Zeng, D. B. Robinson et al., "Monodisperse $\mathrm{MFe}_{2} \mathrm{O}_{4}(\mathrm{M}=\mathrm{Fe}, \mathrm{Co}, \mathrm{Mn})$ Nanoparticles," Journal of the American Chemical Society, vol. 126, no. 1, pp. 273-279, 2004.

[62] H. Deng, X. L. Li, Q. Peng, X. Wang, J. Chen, and Y. Li, "Monodisperse magnetic single-crystal ferrite microspheres," Angewandte Chemie, vol. 44, no. 18, pp. 2782-2785, 2005.

[63] S. Hamada and E. Matijević, "Ferric hydrous oxide sols. IV. Preparation of uniform cubic hematite particles by hydrolysis of ferric chloride in alcohol-water solutions," Journal of Colloid And Interface Science, vol. 84, no. 1, pp. 274-277, 1981.

[64] M. Ozaki, S. Kratohvil, and E. Matijević, "Formation of monodispersed spindle-type hematite particles," Journal of Colloid and Interface Science, vol. 102, no. 1, pp. 146-151, 1984.

[65] K. G. Pradhan and K. M. Parida, "Fabrication, growth mechanism, and characterization of $\alpha-\mathrm{Fe}_{2} \mathrm{O}_{3}$ nanorods," ACS Appied Materials \& Interfaces, vol. 3, pp. 317-323, 2011.

[66] L. P. Zhu, G. H. Liao, N. C. Bing, X. Zhao, and Y. Y. Gu, "Synthesis of monodisperse shuttle-like $\alpha-\mathrm{Fe}_{2} \mathrm{O}_{3}$ nanorods via the EDA-assisted method," Materials Letters, vol. 65, no. 9, pp. 1287-1290, 2011.

[67] R. M. Wang, Y. F. Chen, Y. Y. Fu, H. Zhang, and C. Kisielowski, "Bicrystalline hematite nanowires," Journal of Physical Chemistry B, vol. 109, no. 25, pp. 12245-12249, 2005.

[68] X. Qu, N. Kobayashi, and T. Komatsu, "Solid nanotubes comprising $\alpha-\mathrm{Fe}_{2} \mathrm{O}_{3}$ nanoparticles prepared from ferritin protein," ACS Nano, vol. 4, no. 3, pp. 1732-1738, 2010.

[69] X. G. Wen, S. H. Wang, Y. Ding, Z. L. Wang, and S. Yang, "Controlled growth of large-area, uniform, vertically aligned arrays of $\alpha-\mathrm{Fe}_{2} \mathrm{O}_{3}$ nanobelts and nanowires," Journal of Physical Chemistry B, vol. 109, no. 1, pp. 215-220, 2005.

[70] Y. W. Zhu, T. Yu, C. H. Sow et al., "Efficient field emission from $\alpha-\mathrm{Fe}_{2} \mathrm{O}_{3}$ nanoflakes on an atomic force microscope tip," Applied Physics Letters, vol. 87, no. 2, Article ID 023103, 3 pages, 2005.

[71] H. J. Zhou and S. S. Wong, "A facile and mild synthesis of 1-D $\mathrm{ZnO}, \mathrm{CuO}$, and $\alpha-\mathrm{Fe}_{2} \mathrm{O}_{3}$ nanostructures and nanostructured arrays," ACS Nano, vol. 2, no. 5, pp. 944-958, 2008.

[72] X. H. Wang, L. Zhang, Y. H. Ni, J. Hong, and X. Cao, "Fast preparation, characterization, and property study of $\alpha-\mathrm{Fe}_{2} \mathrm{O}_{3}$ nanoparticles via a simple solution-combusting method," Journal of Physical Chemistry C, vol. 113, no. 17, pp. 70037008, 2009.

[73] F. Mazille, T. Schoettl, N. Klamerth, S. Malato, and C. Pulgarin, "Field solar degradation of pesticides and emerging water contaminants mediated by polymer films containing titanium and iron oxide with synergistic heterogeneous photocatalytic activity at neutral pH," Water Research, vol. 44, no. 10, pp. 3029-3038, 2010.
[74] F. Mazille, A. Lopez, and C. Pulgarin, "Synergistic effect of $\mathrm{TiO}_{2}$ and iron oxide supported on fluorocarbon films. Part 2: long-term stability and influence of reaction parameters on photoactivated degradation of pollutants," Applied Catalysis $B$, vol. 90, no. 3-4, pp. 321-329, 2009.

[75] N. Murakami, T. Chiyoya, T. Tsubota, and T. Ohno, "Switching redox site of photocatalytic reaction on titanium(IV) oxide particles modified with transition-metal ion controlled by irradiation wavelength," Applied Catalysis A, vol. 348, no. 1, pp. 148-152, 2008.

[76] M. H. Rasoulifarda, H. H. Monfareda, and S. Masoudiana, "Photo-assisted hetero-Fenton decolorization of azo dye from contaminated water by $\mathrm{Fe}-\mathrm{Si}$ mixed oxide nanocomposite," Environmental Technology, vol. 32, no. 14, pp. 16272635, 2011.

[77] C. H. Ho, Y. J. Huang, and Y. H. Huang, "Degradation of azo dye reactive black b using an immobilized iron oxide in a batch photo-fluidized bed reactor," Environmental Engineering Science, vol. 27, no. 12, pp. 1043-1048, 2010.

[78] Y. Wang, W. P. Du, and Y. M. Xu, "Effect of sintering temperature on the photocatalytic activities and stabilities of hematite and silica-dispersed hematite particles for organic degradation in aqueous suspensions," Langmuir, vol. 25, no. 5, pp. 2895-2899, 2009.

[79] Q. Lan, F. Li, C. Liu, and X. Z. Li, "Heterogeneous photodegradation of pentachlorophenol with maghemite and oxalate under UV illumination," Environmental Science \& Technology, vol. 42, no. 21, pp. 7918-7923, 2008.

[80] F. B. Li, X. Z. Li, X. M. Li, T. X. Liu, and J. Dong, "Heterogeneous photodegradation of bisphenol A with iron oxides and oxalate in aqueous solution," Journal of Colloid and Interface Science, vol. 311, no. 2, pp. 481-490, 2007.

[81] Y. Wang, C. S. Liu, F. B. Li, C. P. Liu, and J. B. Liang, "Photodegradation of polycyclic aromatic hydrocarbon pyrene by iron oxide in solid phase," Journal of Hazardous Materials, vol. 162, no. 2-3, pp. 716-723, 2009.

[82] X. Z. Li, H. Liu, L. F. Cheng, and H. J. Tong, "Photocatalytic oxidation using a new catalyst- $\mathrm{TiO}_{2}$ microsphere-for water and wastewater treatment," Environmental Science \& Technology, vol. 37, no. 17, pp. 3989-3994, 2003.

[83] B. H. Lai, C. C. Yeh, and D. H. Chen, "Surface modification of iron oxide nanoparticles with polyarginine as a highly positively charged magnetic nano-adsorbent for fast and effective recovery of acid proteins," Process Biochemistry, vol. 47, no. 5, pp. 799-805, 2012.

[84] D. Das, S. Roy, J. W. Chen, and D. Chakravorty, "Interface controlled electrical and magnetic properties in $\mathrm{Fe}_{-} \mathrm{Fe}_{3} \mathrm{O}_{4}$ silica gel nanocomposites," Journal of Applied Physics, vol. 91, no. 7, pp. 4573-4579, 2002.

[85] T. Nakamura, Y. Yamada, and K. Yano, "Novel synthesis of highly monodispersed $\gamma-\mathrm{Fe}_{2} \mathrm{O}_{3} / \mathrm{SiO}_{2}$ and $\varepsilon$ - $\mathrm{Fe}_{2} \mathrm{O}_{3} / \mathrm{SiO}_{2}$ nanocomposite spheres," Journal of Materials Chemistry, vol. 16, no. 25, pp. 2417-2419, 2006.

[86] L. F. González-Bahamón, F. Mazille, L. N. Benítez, and C. Pulgarín, "Photo-Fenton degradation of resorcinol mediated by catalysts based on iron species supported on polymers," Journal of Photochemistry and Photobiology A, vol. 217, no. 1, pp. 201-206, 2011.

[87] J. Fernandez, J. Bandara, A. Lopez, P. Buffat, and J. Kiwi, "Photoassisted Fenton degradation of nonbiodegradable azo dye (Orange II) in Fe-free solutions mediated by cation transfer membranes," Langmuir, vol. 15, no. 1, pp. 185-192, 
1999.

[88] M. Rios-Enriquez, N. Shahin, C. D. Bazua et al., "Optimization of the heterogeneous Fenton-oxidation of the model pollutant 2,4-xylidine using the optimal experimental design methodology," Solar Energy, vol. 77, no. 5, pp. 491-501, 2004.

[89] C. L. Hsueh, Y. H. Huang, and C. Y. Chen, "Novel activated alumina-supported iron oxide-composite as a heterogeneous catalyst for photooxidative degradation of reactive black 5," Journal of Hazardous Materials, vol. 129, no. 1-3, pp. 228233, 2006.

[90] S. Azabou, W. Najjar, A. Gargoubi, A. Ghorbel, and S. Sayadi, "Catalytic wet peroxide photo-oxidation of phenolic olive oil mill wastewater contaminants. Part II. Degradation and detoxification of low-molecular mass phenolic compounds in model and real effluent," Applied Catalysis B, vol. 77, no. 1-2, pp. 166-174, 2007.

[91] M. I. Pariente, F. Martínez, J. A. Melero et al., "Heterogeneous photo-Fenton oxidation of benzoic acid in water: effect of operating conditions, reaction by-products and coupling with biological treatment," Applied Catalysis B, vol. 85, no. 1-2, pp. 24-32, 2008.

[92] X. R. Zhao, L. H. Zhu, Y. Y. Zhang et al., "Removing organic contaminants with bifunctional iron modified rectorite as efficient adsorbent and visible light photo-Fenton catalyst," Journal Hazardours Materials, vol. 215, pp. 57-64, 2012.

[93] X. M. Zhou, J. Y. Lan, G. Liu et al., "Facet-mediated photodegradation of organic dye over hematite architectures by visible light," Angewandte Chemie, vol. 51, pp. 178-182, 2012.

[94] A. Dhakshinamoorthy, S. Navalon, M. Alvaro, and H. Garcia, "Metal nanoparticles as heterogeneous Fenton catalysts," ChemSusChem, vol. 5, no. 1, pp. 46-64, 2012.

[95] K. Nam, W. Rodriguez, and J. J. Kukor, "Enhanced degradation of polycyclic aromatic hydrocarbons by biodegradation combined with a modified Fenton reaction," Chemosphere, vol. 45 , no. 1, pp. 11-20, 2001.

[96] D. H. Lin, X. L. Tian, F. C. Wu, and B. S. Xing, "Fate and transport of engineered nanomaterials in the environment," Journal of Environmental Quality, vol. 39, no. 6, pp. 18961908, 2010.

[97] W. H. Fan, M. M. Cui, H. Liu et al., "Nano-TiO ${ }_{2}$ enhances the toxicity of copper in natural water to Daphnia magna," Environmental Pollution, vol. 159, no. 3, pp. 729-734, 2011.

[98] D. M. Wang, J. Hu, D. R. Irons, and J. M. Wang, "Synergistic toxic effect of nano- $\mathrm{TiO}_{2}$ and $\mathrm{As}(\mathrm{V})$ on Ceriodaphnia dubia," Science of the Total Environment, vol. 409, no. 7, pp. 13511356, 2011.

[99] J. Hu, D. Wang, J. T. Wang, and J. M. Wang, "Bioaccumulation of $\mathrm{Fe}_{2} \mathrm{O}_{3}$ (magnetic) nanoparticles in Ceriodaphnia dubia," Environmental Pollution, vol. 162, pp. 216-222, 2012.

[100] T. J. Brunner, P. Wick, P. Manser et al., "In vitro cytotoxicity of oxide nanoparticles: comparison to asbestos, silica, and the effect of particle solubility," Environmental Science \& Technology, vol. 40, no. 14, pp. 4374-4381, 2006.

[101] T. R. Pisanic II, J. D. Blackwell, V. I. Shubayev, R. R. Fiñones, and S. Jin, "Nanotoxicity of iron oxide nanoparticle internalization in growing neurons," Biomaterials, vol. 28, no. 16, pp. 2572-2581, 2007.

[102] H. Schwegmann, A. J. Feitz, and F. H. Frimmel, "Influence of the zeta potential on the sorption and toxicity of iron oxide nanoparticles on S. cerevisiae and E. coli," Journal of Colloid and Interface Science, vol. 347, no. 1, pp. 43-48, 2010.

[103] B. A. Katsnelson, T. D. Degtyareva, I. I. Minigalieva et al.,
"Subchronic systemic toxicity and bioaccumulation of $\mathrm{Fe}_{3} \mathrm{O}_{4}$ nano- and microparticles following repeated intraperitoneal administration to rats," International Journal of Toxicology, vol. 30, no. 1, pp. 59-68, 2011.

[104] T. Phenrat, T. C. Long, G. V. Lowry, and B. Veronesi, "Partial oxidation ("aging") and surface modification decrease the toxicity of nanosized zerovalent iron," Environmental Science \& Technology, vol. 43, no. 1, pp. 195-200, 2009. 


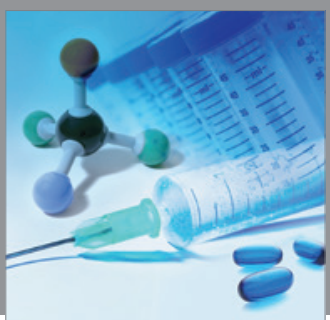

International Journal of

Medicinal Chemistry

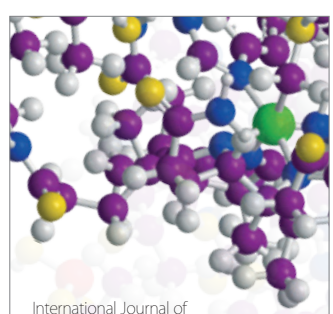

Carbohydrate Chemistry

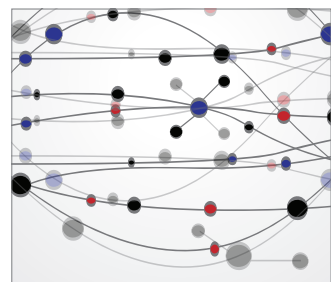

The Scientific World Journal
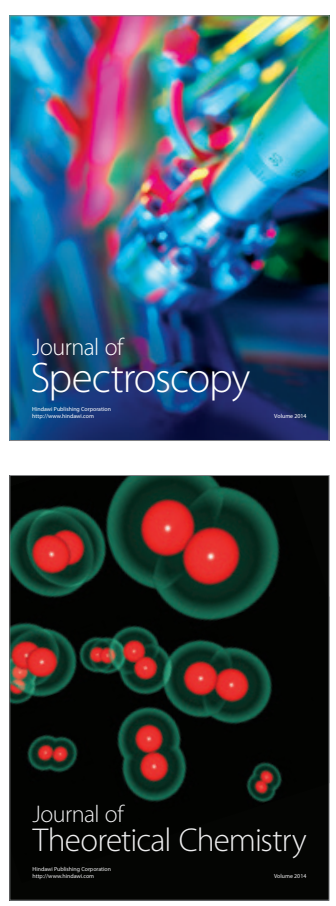
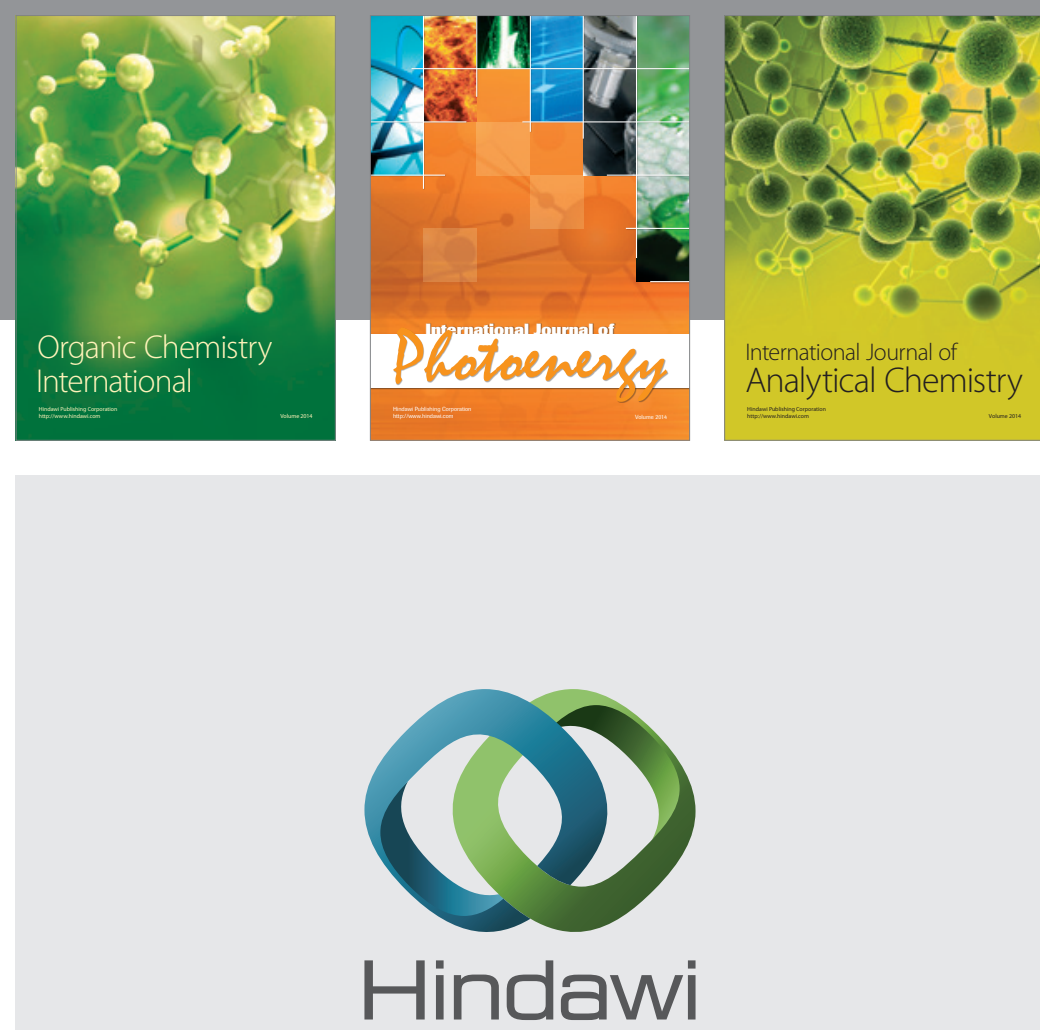

Submit your manuscripts at

http://www.hindawi.com
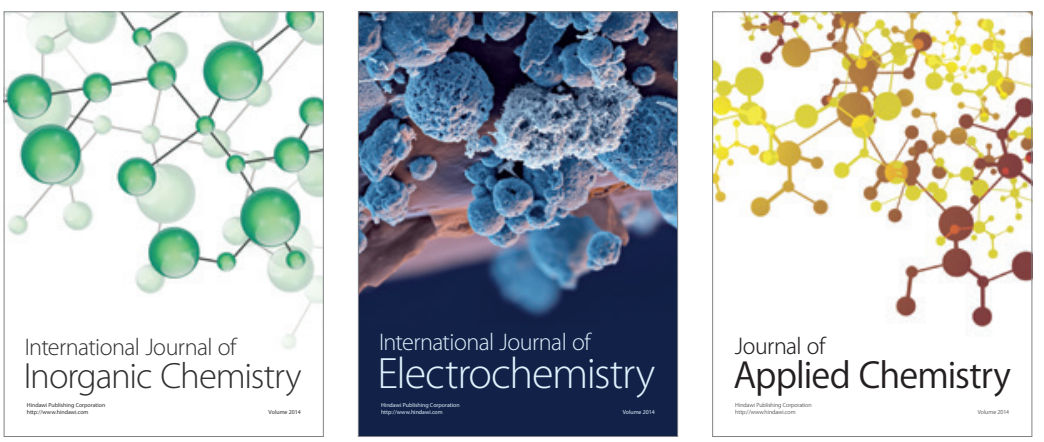

Journal of

Applied Chemistry
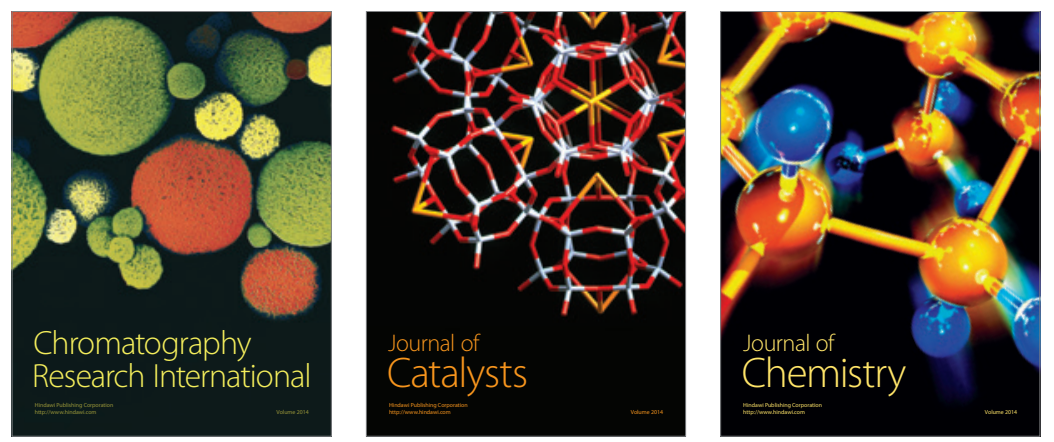
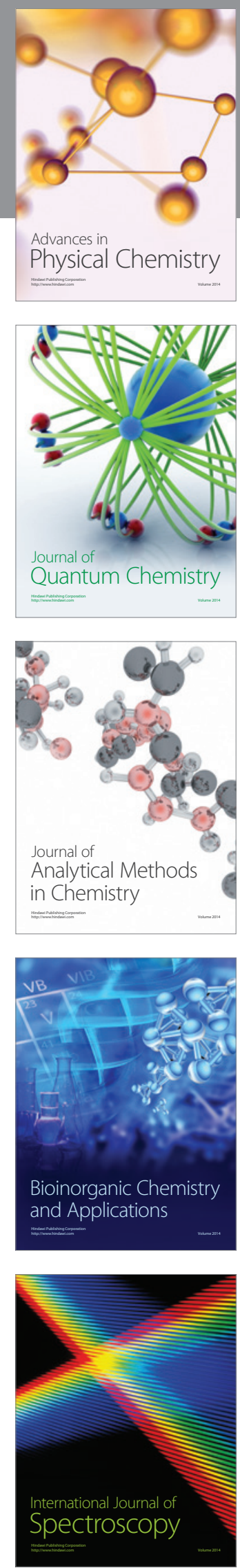